\title{
地盤沈下を受ける埋設管路の挙動に関する二，三の考察 \\ CONSIDERATIONS ON BEHAVIOUR OF UNDERGROUND PIPELINES CAUSED BY GROUND SETTLEMENT
}

大石 博*

By Hiroshi OISHI

\begin{abstract}
Recently underground pipelines have been constructed in the places where large ground settlement could occur. And many underground pipelines were destroyed by the ground settlement due to liquefaction and so on in the past earthquakes. In designing underground pipelines, ground settlement is considered to be one of the most important problems.

In view of these facts, ground settlement which has influence on underground pipelines was classified into 3 patterns. And for the most critical pattern both analytical and experimental investigations were executed. As the result were confirmed the effectiveness of not only the proposed basic countermeasure for the critical ground settlement pattern but the adaptation of the linear analytical solution to the nonlinear region of ground spring.
\end{abstract}

\section{1. まえがき}

都市の近代化に伴い, 各種管路が地中に埋設されるこ とが，非常に多くなってきている．これらの建設の増大 に伴い，相当な地盤沈下（不等沈下を含む）が予想され る地域への埋設管路の建設が，避けることのできない状 況にある. 一方, 1964 年の新潟地震において, 地盤の 液状化により, 埋設管路は, 多くの被害を受けているが゙， これらの被害原因の 1 つとして, 地盤の液状化終了後に 発生する地盤沈下によることが考えられる.また, 1978

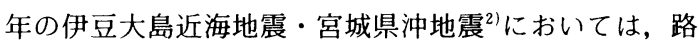
肩部分や造成宅地の盛土部分の地盤沈下により, 埋設管 路は, 多くの被害を受けている.

そこで，埋設管路の地盤沈下問題を，解析的・実験的 に検討し，その挙動を明らかにするとともに，適切な対 策案を検討することは, 工学上, きわめて重要なことで ある・

このような観点より，埋設管路に影響を与える地盤沈 下形態を, 3 つのパターンに分類し, その中で, 単位沈 下量に対して最も発生断面力の大きいパターンに関し, 基本的対策案を含めた解析的検討を実施した. また, 解

* 正会員 工修 日本鋼管(株)中央研究所主任部員 ( ₹210 川崎市川崎区南渡田町 1-1)
析解および基本的対策案の有効性の検討のため, 土槽を 用いた地盤沈下実験を実施した。

本論文は，地盤沈下を受ける埋設管路の挙動に関する 解析的・実験的検討結果と, 大きな地盤沈下量の取扱い, すなわち, 地盤ばねの非線形領域における線形解析解の 適用性について，言及したものである.

\section{2. 地盤沈下による埋設管路挙動の解析的検討}

\section{（1）埋設管路に影筍を与える地盤沈下形態と その解析解}

埋設管路に影響を与える地盤沈下の原因 ${ }^{31}$ として,

1）盛土などによる上載荷重の増加あるいは, 地下水 位低下なよ゙による粘性土層の圧密沈下.

2）埋戻し土砂の安定までに発生する沈下.

3）開削工事に伴う山留工の変形やシールド工事なよ゙ 他工事によって引き起こされる沈下.

4）地震時に, 砂地盤の液状化や道路の路肩部分・造 成地の盛土部分の部分的破壊によって発生する急激 な视下.

などが考えられる。

これら原因は, 種々考えられるが，これら埋設管路に 影響を与える地盤沈下形態を, Fig. 1 に示すような 3 つ の簡易なモデルに置換する. Fig. 1 に示す 3 つの夕イプ 


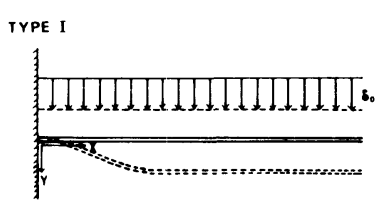

IYPE II

T]IIIIIIIIIIIIII.
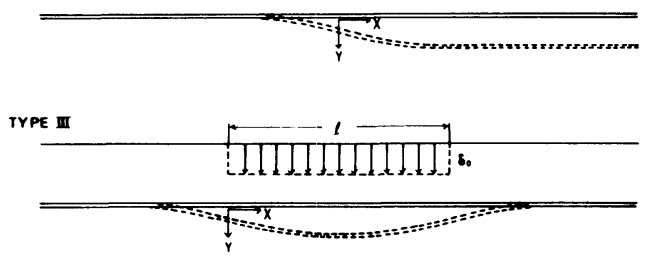

Fig. 1 Analytical Model.

に関して，管路は，地盤と弾性的なばねで結ばれている とし，その解析解を誘導する.

タイプ I ・ II ・III基本的なつり合い方程式は,

EI $\frac{d^{4} y}{d x^{4}}+K_{y}\left(y-y_{G}\right)=0$

である.ここで, $y:$ 管路の変位, $E I$ : 管路の断面剛性, $K_{y}$ : 管路に作用する地盤ばね定数, $y_{G}$ : 地盤の変位, である.

タイプ I・II・III関する境界条件を用いて, 式 (1) を解くと, 管路変位 $y$ は,

タイプIに関して,

$y_{\mathrm{I}}=\delta_{0}\left\{1-\sqrt{2} e^{-\beta x} \cdot \sin \left(\beta x+\frac{\pi}{4}\right)\right\}$

タイプIIに関しで,

$y_{\mathbb{1} 1}=\delta_{0} \cdot e^{\beta x} \cdot \cos \beta x / 2 \quad(x<0)$

$y_{\mathbb{}}=\delta_{0} \cdot\left(1-e^{-\beta x} \cdot \cos \beta x / 2\right) \quad(x \geqq 0)$

タイプ吕に関して ${ }^{5)}$,

$y_{\text {III } 1}=\delta_{0}\left\{e^{\alpha x} \cdot \cos \beta x-e^{\alpha x-l)} \cdot \cos \beta(x-l)\right\}$

$y_{\text {II } 2}=\delta_{0}-\frac{\delta_{0}}{2}\left\{e^{-\beta x} \cdot \cos \beta x+e^{A x-l)} \cdot \cos \beta(x-l)\right\}$

$(0 \leqq x<l)$

$y_{\mathbb{\|} 3}=\frac{\delta_{0}}{2}\left\{-e^{-\beta x} \cdot \cos \beta x+e^{-\alpha x-l)} \cdot \cos \beta(x-l)\right\}$

$(x \geqq l)$

となる.ここで, $\delta_{0}$ : 地盤沈下量, $l$ : 地盤沈下愊, $\beta^{4}$ $=K_{\mathbf{y}} / 4 E I$, である.

式（2），(3)，(4) より求められる各タイプの最大 曲げモーメントは,

$$
\begin{aligned}
& M_{\mathrm{I} \max }=-2 E I \delta_{0} \cdot \beta^{2} \quad: x=0 \\
& M_{\text {I } \max }=E I \cdot \delta_{0} \cdot \beta^{2} \cdot e^{-\frac{\pi}{4} / \sqrt{2}}: x=\pi / 4 \beta
\end{aligned}
$$

$$
\begin{aligned}
M_{\mathbb{I} \max }= & 2 E I \cdot \delta_{0} \cdot \beta^{2} \cdot e^{-\frac{\pi}{4} / \sqrt{2}} \\
& : x=\pi / 4 \beta \text { かつ } l=\pi / 2 \beta
\end{aligned}
$$

となる. タイプII は, タイプIIIの地盤沈下幅 $l$ が, 無限 大になった場合と考えられ，タイプ四において，l= $/ 2 \beta$ のとき, $M_{\text {【 } \max }=2 M_{\text {I } \max }$ になる. タイプI・II・ III の最大曲げモーメントの比を取ると，

$$
M_{\text {I } \max }: M_{\amalg \max }: M_{\mathbb{I} \max }=6.2: 1.0: 2.0
$$

となり,タイプIの地盤沈下形態は, 同一沈下量に対し て，タイプII の 6.2 倍の断面力が発生することになる. つまり，タイプIは，地盤沈下による埋設管路の挙動を 考える場合, 最も考慮すべき地盤沈下形態といえる.

\section{（2）地盤沈下形態の変化と埋設管路発生断面力}

タイプ I の地盤沈下形態の場合に，他の 2 つのタイプ より発生断面力が大きいのは, 固定構造物とその周辺地 盤との間に大きな相対変位が生じるのと, 管路の一端が 固定構造物に固定されているためである.

タイプIに関する地盤沈下対策法として，種々な方法 が考えられるが，ここでは，Fig.2に示すように，管路 の下に沈下防止板を設け, 固定構造物周辺の地盤沈下形 状を変化させた場合，管路に発生する断面力がどのよう に変化するかについて, 解析的に検討する.

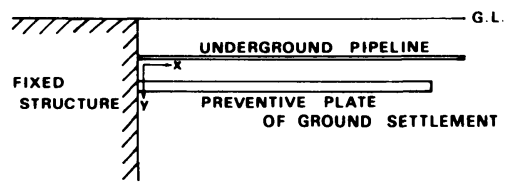

Fig. 2 Model of Preventive Plate of Ground Settlement.

解析解の誘導にあたって, 地盤の沈下形状は, 沈下防 止板により, 次式のように変化するとする.

$$
y_{G}=\delta_{0}\left\{1-\sqrt{2} e^{-\beta^{\prime} x} \cdot \sin \left(\beta^{\prime} x+\frac{\pi}{4}\right)\right\}
$$

式（1）を，境界条件および式（7）を用いて解くと,

$$
\begin{aligned}
y_{\mathrm{I}^{\prime}}= & \delta_{0}\left\{1-\frac{\sqrt{2} \beta^{4}}{\beta^{4}-\beta^{\prime 4}} \cdot e^{-\beta^{\prime} x} \cdot \sin \left(\beta^{\prime} x+\frac{\pi}{4}\right)\right. \\
& \left.+\frac{\sqrt{2} \beta^{\prime 4}}{\beta^{4}-\beta^{\prime 4}} \cdot e^{-\beta x} \cdot \sin \left(\beta x+\frac{\pi}{4}\right)\right\} \cdots \cdots \cdots
\end{aligned}
$$

となる.ここで， $\beta^{\prime \prime}=K_{y}^{\prime} / 4 E^{\prime} I^{\prime} \quad K_{y}^{\prime}$ : 沈下防止板に作 用する地盤ばね定数, $E^{\prime} I^{\prime}$ : 沈下防止板の断面剛性,で ある.

式（８）より, 最大曲げモーメントを求めると,

$$
M_{I^{\prime} \max }=-2 E I \cdot \delta_{0} \cdot \beta^{2} \cdot\left\{\frac{1}{1+\left(\beta \mid \beta^{\prime}\right)^{2}}\right\}
$$

となり,タイプIの最大曲げモーメントとの関係は,

$$
M_{I^{\prime} \max }=\left\{\frac{1}{1+\left(\beta \mid \beta^{\prime}\right)^{2}}\right\} \cdot M_{\mathrm{I} \max }
$$




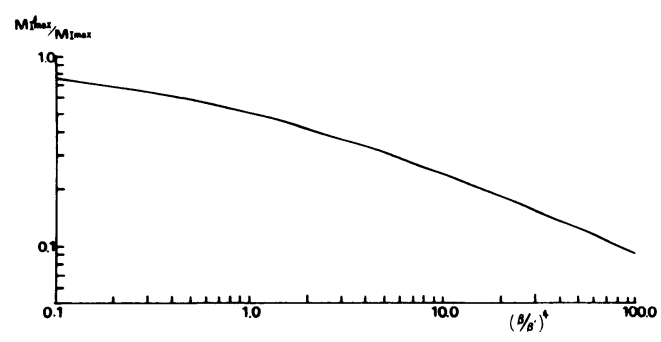

Fig. 3 Effeciveness of Preventive Plate of Ground Settelement.

となる.つまり, $\beta / \beta^{\prime}$ の値を大きくしていくことにより， 管路に発生する最大断面力は，小さくなる．沈下防止板 の効果の定量的な評価のため, $\beta / \beta^{\prime}$ と $M_{\mathrm{I}} \max / M_{\mathrm{I} \max }$ との関係を, Fig. 3 に示す.つまり, 沈下防止板は, 夕 イプIの地盤沈下形態に対する管路発生断面力の低減に 関し，非常に有効な手段の 1 つであるといえる.

\section{3. 地盤沈下による埋設管路挙動の実験的検討}

\section{（1）実験 概 要}

a ) 実験装置の概要

Fig. 4 に，実験装置の全体 図を示す．実験に使用した土槽の寸法は, $2 \mathrm{~m} \times 2 \mathrm{~m}$ $\times 1.5 \mathrm{~m}$ であり，土槽の外側に，2.5 m×2.5 m×0.7 m の水槽がある. 土槽の底部には, $75 \mathrm{~mm}$ 間隔に, $\phi$ $13 \mathrm{~mm}$ の穴が, 313 個あいており, 水槽内の水が自由に, 土槽内に入るようにしている.

b ）埋設管路および沈下防止板モデル＼cjkstart実験に用 いた管路モデルは， さ $1850 \mathrm{~mm}$ ) であり, 沈下防止板モデルは, 幅 $150 \mathrm{~mm}$ ×厚さ $(20 \mathrm{~mm}$ または $40 \mathrm{~mm}) \times$ 長さ $(500 \mathrm{~mm}$ または $1000 \mathrm{~mm}$ ) のアクリル板である. Fig. 4 に示すように,

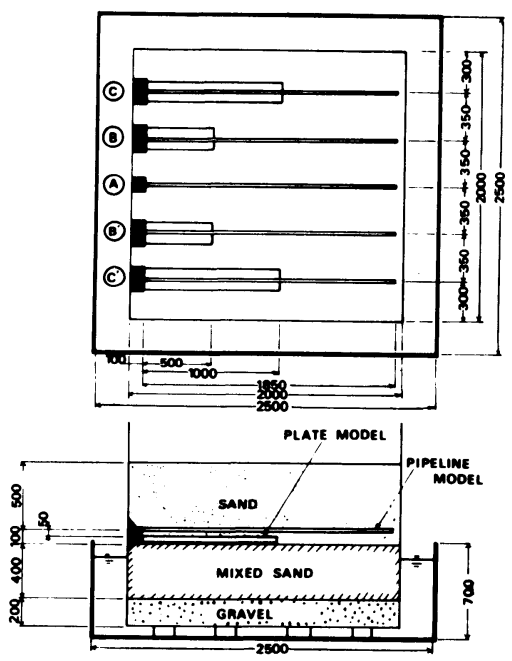

Fig. 4 General View of Experimental Apparatus.
管路モデルと沈下防止板モデルとの間隔は, $50 \mathrm{~mm}$ で あり，管路モデル，沈下防止板モデルとも，一端が治具 で土槽の側板に固定されている，モデルA は，沈下防 止板なし，モデル B は, $150 \mathrm{~mm} \times 20 \mathrm{~mm} \times 500 \mathrm{~mm}$ の 沈下防止板が, モデル C は, $150 \mathrm{~mm} \times 20 \mathrm{~mm} \times 1000$ $\mathrm{mm}$ の沈下防止板が，モデル $\mathrm{B}^{\prime}$ は, $150 \mathrm{~mm} \times 40 \mathrm{~mm} \times$ $500 \mathrm{~mm}$ の沈下防止板が，モデル $C^{\prime}$ は, $150 \mathrm{~mm} \times 40$ $\mathrm{mm} \times 1000 \mathrm{~mm}$ の沈下防止板が, 設置されている.

c ) 測定計器測定に用いた計器配置を, Fig. 5 に示す．管路ひずみおよび管路・地盤沈下量に関して， 測定を実施している，管路ひずみに関しては，各アクリ ル丸棒の 10 断面, 各断面の天・地の 2 点の測定を, 管 路沈下量に関しては，3 地点，表層地盤の沈下量に関し ては, 24 地点の測定を，行っている.

d） 実験地盤の構成亡地盤の土質特性 土槽内の 地盤構成は，Fig. 4 に示すように，底面より高さ 200 $\mathrm{mm}$ が, 砕石 6 号, 高さ $200 \mathrm{~mm}$ より $600 \mathrm{~mm}$ が, 山砂 (浅 間山産）と硫安を $2: 3$ に混合した混合士 ${ }^{6}$, 高さ 600 $\mathrm{mm}$ より $1200 \mathrm{~mm}$ が, 山砂, である. 混合土および山 砂は, $100 \mathrm{~mm}$ ごとに均等な締め固めを行っている. ま た，管路モデルは，500 mm の土かぶりを有しており， 管路および沈下防止板モデルは，山砂層内に埋設されて いる.

本実験は，混合土内への水の浸透による硫安の溶解に より, 混合土の体積が減少し, 山砂層が沈下することに 依存している.Fig. 6 に，実験に用いた山砂の粒径加積 曲線を示す。なお, 山砂層は, 乾燥密度 $1.39 \mathrm{~g} / \mathrm{cm}^{3}$, 含水比 $12.2 \%$ の状態にある. また，Fig. 7 に，山砂表 層中央において実施した平板載荷試験の結果を示す， $P$ $\sim \delta$ 曲線は, $\delta=1.0 \mathrm{~cm}$ 付近より傾きに大きな変化が現 われ，初期の傾きは, $2.0 \sim 3.0 \mathrm{~kg} / \mathrm{cm}^{3}(19.6 \sim 29.4$ $\left.\mathrm{MN} / \mathrm{m}^{3}\right)$ 程度であるが, $\delta=3.0 \mathrm{~cm}$ 付近における接線 勾配は, $0.05 \sim 0.10 \mathrm{~kg} / \mathrm{cm}^{3}\left(0.49 \sim 0.98 \mathrm{MN} / \mathrm{m}^{3}\right)$ で

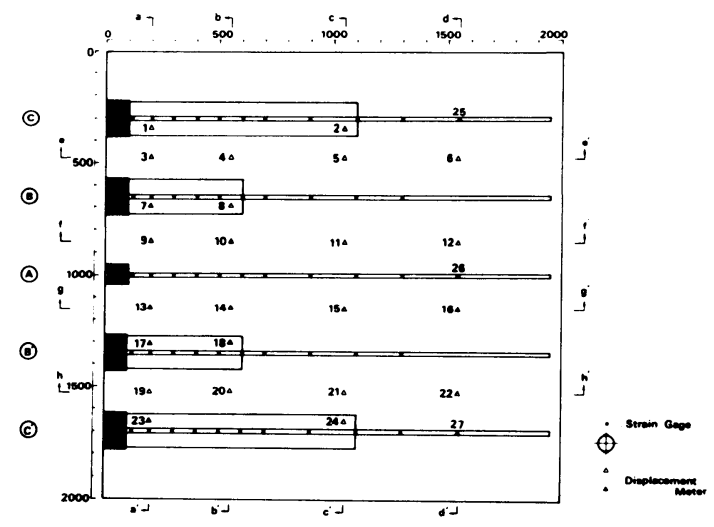

Fig. 5 Location of Instruments. 


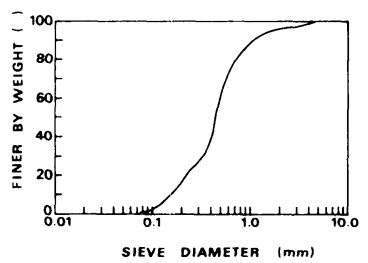

Fig. 6 Grain Size Accumulation Curve of Soil.

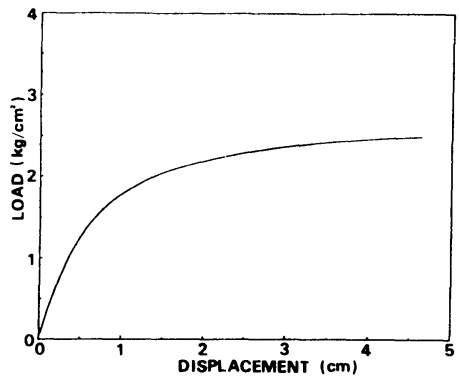

Fig. 7 Result of Plate Bearing Test of Surface Layers.

ある。

e ）実験工程本実験は，1982 年 12 月 13 日より， 1983 年 1 月 22 日に実施した. 12 月 24 日午前中に, 実 験準備をすべて終了し，同日 14 時より，すべての計測 器を用いた予備測定に入った。なお，管路のひずみ測定 は，12月 16 日 16 時より実施している。また，1月 10 日 10 時より水槽内への注水を開始し，本実験に入った. なお, 計測器の初期值は, 1 月 10 日 10 時の本実験開始 時, および, 実験準備時, 予備測定時に, 計 5 回, 取っ ている.

\section{（2）実験結果および考察}

a）地盤および管路の沈下 Fig.8に, Fig.5の $f-f^{\prime}$ 断面における地盤沈下の経時変化を示す. 地盤の 沈下量は, 時間の経過とともに増大しており，特に，初 期注水時および水槽内の水の交換時（3 日目）に，その 変化は大きい.

Fig. 9 に，管路モデルに直交する $b^{-b^{\prime}}$ 断面の沈下分 布図，Fig. 10 に，d-d'断面の沈下分布図を示す， b-b' 断面においては, 沈下防止板の剛性の差異により, 管 路モデル B·C の近傍の方が, 管路モデル $\mathrm{B}^{\prime} \cdot \mathrm{C}^{\prime}$ の近傍 より大きな沈下量を示しており，管路モデルAの近傍 は，より大きな沈下量を示している， d- $\mathrm{d}^{\prime}$ 断面におい ては, ほぼ一定の沈下量を示しており, 管路の视下量は, その周辺地盤の沈下量と，ほぼ同一である.

本実験においては, 土槽内に, 一様な沈下を発生させ ようとしたが，全体として， d-d'断面側において，よ り大きい沈下が発生している.

b ）管路ひずみ Fig.11に，管路モデルA の本実

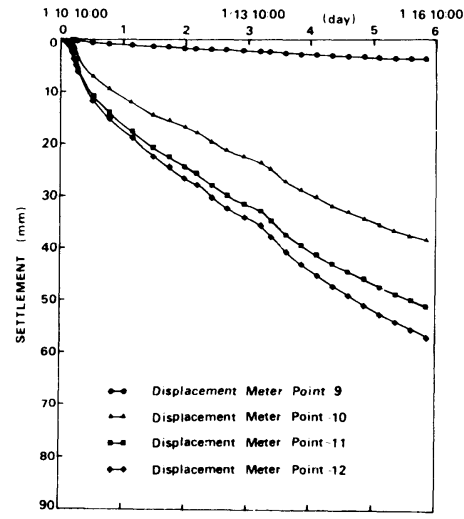

Fig. 8 Time Curve of Ground Settlement (Section $f-f^{\prime}$ ).

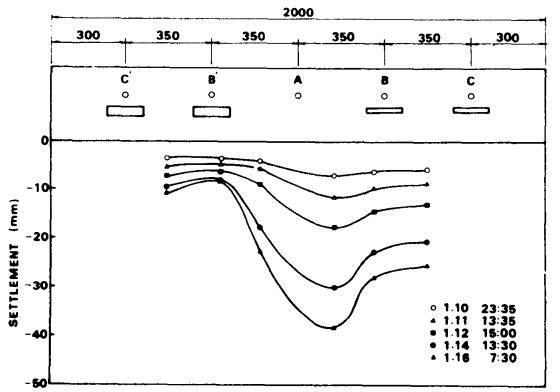

Fig. 9 Change of Distribution of Ground Settlement (Section $b^{-} b^{\prime}$ ).

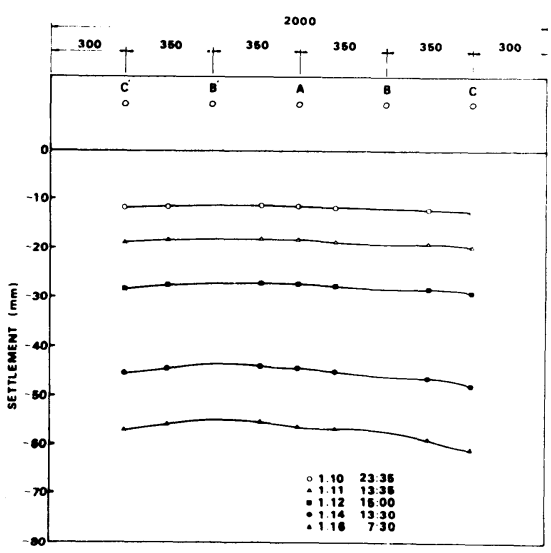

Fig. 10 Change of Distribution of Ground Settlement (Section $d-d^{\prime}$ ).

験におけるひずみ分布の経時変化を示す。なお，図中の 実線は，管路モデルの上側のひずみを，破線は，管路モ デルの下側のひずみを, 示す. 沈下量が一様である場合, 曲げモーメントによるひずみは, はじめ, 固定端より, $\pi / 4 \beta$ の位置に，次に $5 \pi / 4 \beta$ の位置に，0を示す．実 験結果においては, 固定端より $25 \mathrm{~cm}$ 周辺の点におい て,ひずみ值は，0を示しているので，沈下量が一様で 


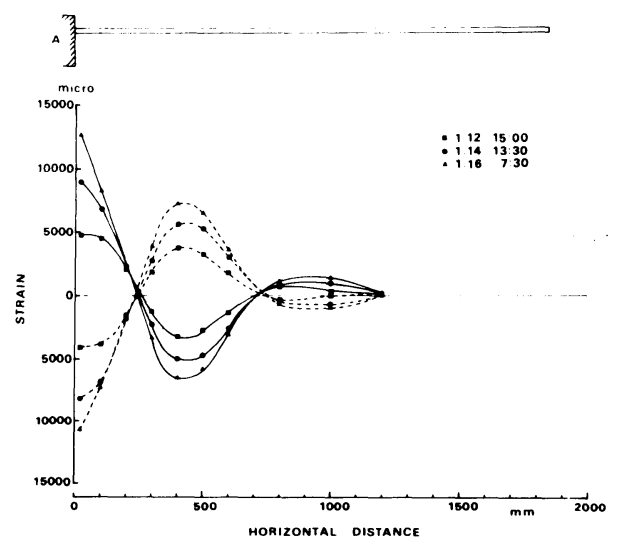

Fig. 11 Change of Distribution of Pipe Strain (Pipe Model A).

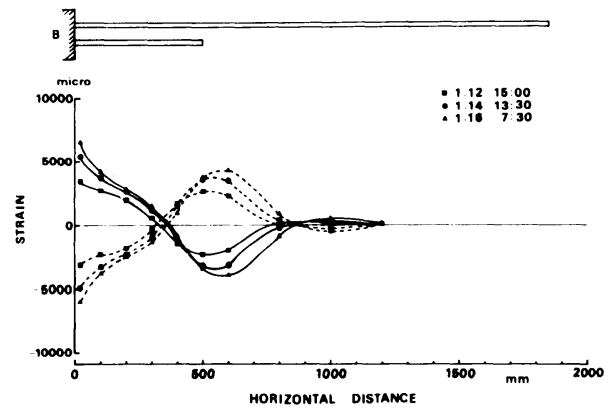

Fig. 12 Change of Distribution of Pipe Strain (Pipe Model B).

あれば，固定端より $125 \mathrm{~cm}$ 周辺において，ひずみ值は， 0 を示すはずである．しかし，実験結果においては，固 定端より $70 \mathrm{~cm}$ 周辺において,ひずみ值が，0を示し ている.また，1月 12 日 15 時のひずみ分布に関しては， 固定端近傍と固定端より $10 \mathrm{~cm}$ 地点におけるひずみ値 が，ほぼ同じ値を示している．これらの現象は，管路モ デルAの周辺地盤が，一様に沈下せず，管路モデル $\mathrm{B} \cdot \mathrm{B}^{\prime}$ の沈下防止板モデルの影響で，固定端上り $50 \mathrm{~cm}$ 周辺に不連続な沈下が地盤中に発生しているためだと思 われる。

Fig. 12 に，管路モデル B のひずみ分布の経時変化を 示す. 実験結果において, 固定端近傍のほかに, 固定端 より $60 \mathrm{~cm}$ 周辺に，大きなひずみ值が，現われている. これは, 沈下防止板モデルが, 固定端より $50 \mathrm{~cm}$ 之短く, 沈下防止板の端点における沈下量が，周辺の地盤沈下量 と一致せず，固定端より $50 \mathrm{~cm}$ 周辺において，不連続 な沈下が, 地盤中に発生しているためだと思われる.

Fig. 13 に，管路モデル B' のひずみ分布の経時変化を 示す．本モデルにおいては，固定端近傍よりも，固定端 より $50 \mathrm{~cm}$ と $80 \mathrm{~cm}$ 周辺に，大きなひずみ值が，現わ

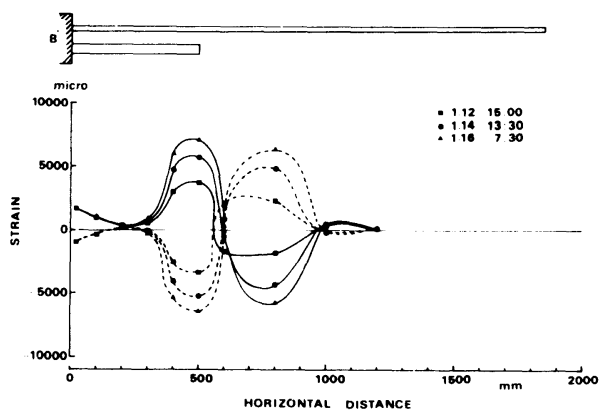

Fig. 13 Change of Distribution of Pipe Strain (Pipe Model $\mathrm{B}^{\prime}$ ).

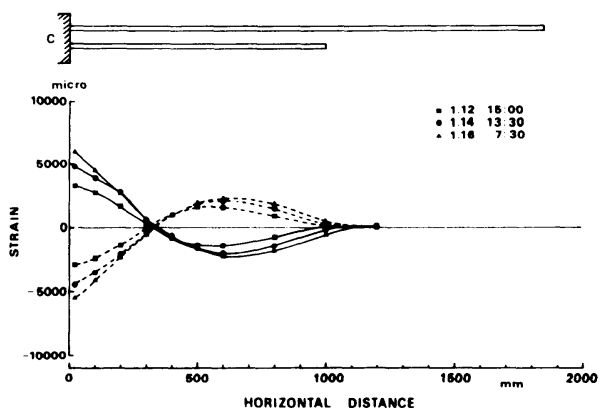

Fig. 14 Change of Distribution of Pipe Strain (Pipe Model C).

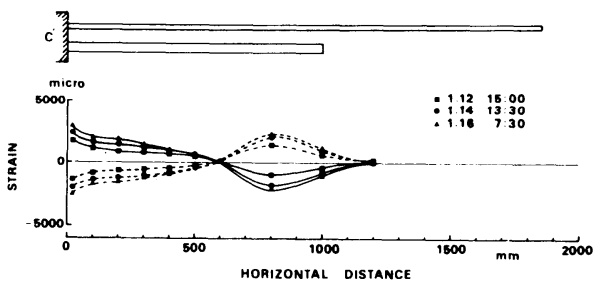

Fig. 15 Change of Distribution of Pipe Strain (Pipe Model $\mathrm{C}^{\prime}$ ).

れている.これは，管路モデル B の場合と同様，沈下 防止板モデルが, 固定端より $50 \mathrm{~cm}$ と短く, かつ, 沈 下防止板モデル自体の曲げ剛性が，管路モデル B の場 合の 8 倍と大きいため, より大きい不連続な沈下が，地 盤中に発生しているためだと思われる.

Fig. 14 に，管路モデル C のひずみ分布の経時変化を 示す．本モデルの视下防止板は，固定端よりの長さが， 管路モデル B の場合の 2 倍の $100 \mathrm{~cm}$ であるため, 沈下 防止板の端点の沈下量は, 周辺地盤の沈下量と, 解析的 には，ほぼ一致する．そのため，実験結果は，式（8) を用い計算される解析値に近いひずみ分布を示してい る. 本モデルの固定端の解析的な曲げひずみ值は，管路 モデル A の 0.47 倍になる (Fig. $3 の ~\left(\beta / \beta^{\prime}\right)^{4}=1.70$ にあ たる)。実験結果による両者の比は， 0.48 であり，ほぼ 


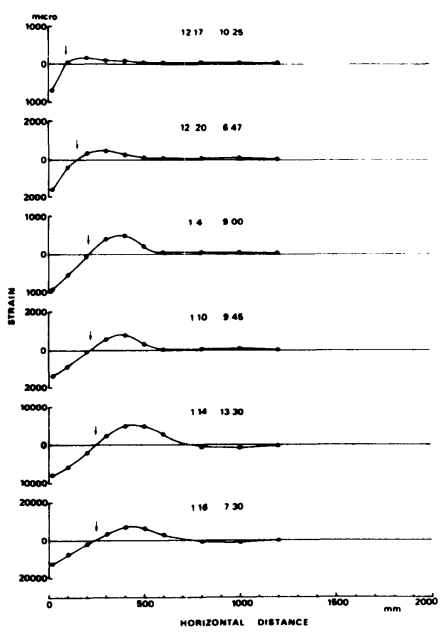

Fig. 16 Change of Distribution of Bending Strain (Pipe Model A).

解析結果に一致しており, 沈下防止板の有効性を示して いる.

Fig. 15 に，管路モデル C' のひずみ分布の経時変化を 示す． 沈下防止板モデルの長さが，管路モデル $\mathrm{B}^{\prime}$ の場 合の 2 倍の $100 \mathrm{~cm}$ であるが, 曲げ剛性は，管路モデル C の場合の 8 倍と大きいため, 沈下防止板モデルの端 点において, 若干の不連続な沈下が, 地盤中に発生して いることが，解析的に考えられる. 固定端より $80 \mathrm{~cm}$ 周辺の位置に, 若干大きなひずみ值が現われているのは, そのためだと思われる. 本モデルの固定端の解析的な曲 げひずみ值は，管路モデル A の 0.24 倍になる (Fig. 3 の $\left(\beta / \beta^{\prime}\right)^{4}=13.6$ にあたる). 実験結果による両者の比 は，0.23であり，ほぼ解析結果に一致しており，この 結果も, 沈下防止板の有効性を示している.

Fig. 11〜15における実験結果より，沈下防止板が， その有効性を十分に発揮するには, その長さは $3 \pi / 4 \beta^{\prime}$ 程度（沈下防止板の端点の沈下量が，周辺地盤の沈下量 に等しくなる沈下防止板の長さ) 必要である, といえる. なお，沈下防止板の適切な曲げ剛性は，必要なモーメン 卜低減率（Fig.3）を考慮し，決定すべきである.

C) 地盤ばねの非線形性 Fig. 16 に, 実験準備時, 予備測定時および本実験時における管路モデル A の曲 げひずみ分布を示す。ここで注目したいのは，時間の経

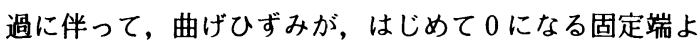
りの距離が，順次長くなっている点である．地盤が一様 に沈下する場合は,曲げひずみがはじめて 0 になる点は, 解析解より, 固定端より $\pi / 4 \beta$ の位置である. そこで, Fig. 16 より求まる曲げひずみが 0 になる固定端よりの 距離と, $\pi / 4 \beta$ より, 地盤ばね定数を逆算すると,

12 月 17 日 10 時 25 分の場合 $k=2.74 \mathrm{~kg} / \mathrm{cm}^{3}$
(26. $9 \mathrm{MN} / \mathrm{m}^{3}$ )

12 月 20 日 6 時 47 分の場合 $k=0.35 \mathrm{~kg} / \mathrm{cm}^{3}$ (3. $43 \mathrm{MN} / \mathrm{m}^{3}$ )

1月 4 日 9 時 0 分の場合 $k=0.092 \mathrm{~kg} / \mathrm{cm}^{3}$ $\left(0.90 \mathrm{MN} / \mathrm{m}^{3}\right)$

1月 10 日 9 時 45 分の場合 $k=0.077 \mathrm{~kg} / \mathrm{cm}^{3}$ (0.76 MN/m ${ }^{3}$ )

1月 14 日 13 時 30 分の場合 $k=0.050 \mathrm{~kg} / \mathrm{cm}^{3}$ $\left(0.49 \mathrm{MN} / \mathrm{m}^{3}\right.$ )

1月 16 日 7 時 30 分の場合 $k=0.050 \mathrm{~kg} / \mathrm{cm}^{3}$ $\left(0.49 \mathrm{MN} / \mathrm{m}^{3}\right)$

となり，地盤沈下の進行に伴って，地盤ばね定数は，小 さくなり，ばねが軟化していることがわかる.

12 月 24 日 14 時に変位計を設置してから，1月10日 10 時に本実験を開始するまでに，地盤は，約 $14 \mathrm{~mm}$ 自 然沈下している。.また，12月 24 日 14 時以前に発生し ている自然沈下量を考慮すると, 本実験開始後における 地盤ばねの状態は, Fig.7 の平板載荷試験結果における 変位 $2 \mathrm{~cm}$ より大きい変位の状態に対応していると考え られる.

\section{4. 解析解の有効性とその適用性}

\section{（1）実験結果による解析解の有効性の検討}

2.において示したタイプI の解析解と，その基本的 対策案に関する解析解の有効性を, 3. に示した実験結 果を用いて論じる．解析解の有効性のために用いた実験 結果は, 予備測定時の 1 月 4 日 9 時 0 分之, 本実験時の 1 月 16 日 7 時 30 分の管路モデル A.C.C'のデータで ある.

Fig. 17 に, 1 月 4 日 9 時 0 分の実測値と解析解とを 比較した図を，Fig. 18 に，1月 16 日 7 時 30 分の実測 値と解析解とを比較した図を示す。なお，解析解に用い た地盤ばね定数は，3.（2)，c）において示した值で あり, 沈下量は, Fig. 5 の point-12の変位量を用いて

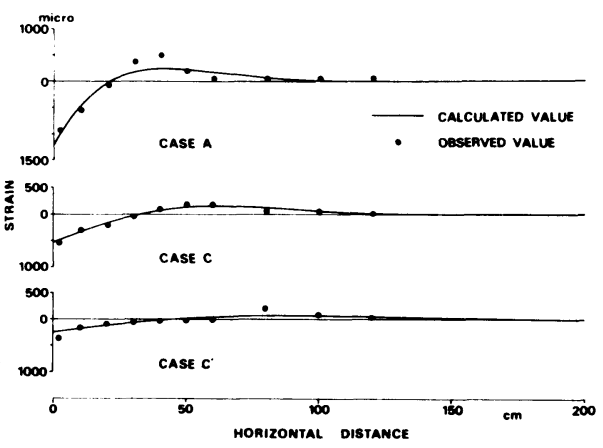

Fig. 17 Comparison between Observed Value and Calculated Value (Data of 4 th January). 


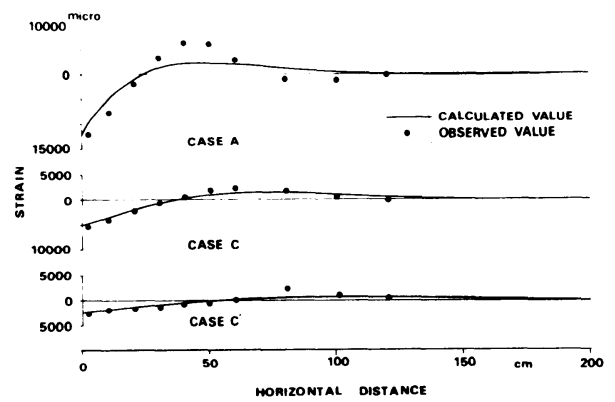

Fig. 18 Comparison between Observed Value and Calculated Value (Data of 16th January).

いる．また，管路モデル C は, $\left(\beta / \beta^{\prime}\right)^{4}=1.70$ であり， 管路モデル $C^{\prime}$ は, $\left(\beta / \beta^{\prime}\right)^{4}=13.6$ である。

Fig. 17, 18 に示すように, 予備測定時および本実験 時の実測ひずみと，2. に示した解析解によるひずみと は, 全体的によく一致している. 管路モデル Aに関して, 固定端より $30 \sim 50 \mathrm{~cm}$ の位置の実測值が，解析ひずみ より大きな値を示しているが,これは，管路モデル $\mathrm{B} \cdot \mathrm{B}^{\prime}$ の沈下防止板モデルの影響によるものであろう し，管路モデル C'に関して，固定端より $80 \mathrm{~cm}$ の位置 の実測ひずみが，解析ひずみより大きな值を示している が,これは, 沈下防止板モデルの剛性により，地盤中に， 若干の不連続な沈下が発生しているためである.

解析解の算定において用いた地盤ばね定数は, 実測さ れた曲げひずみが，0になる点より求めた值を用いてい る. 地盤ばねは, Fig. 7に示す平板載荷試験結果より明 らかなように, 非線形性を示す. しかし, 本解析結果の ように，等価な地盤ばね定数が算定されれば, Fig. 17, 18 に示すように, 線形な解析解においても, 地盤沈下 による埋設管路の挙動を,十分に表現することができる. つまり，2.において示したタイプIおよびその基本的 対策に関する解析解は, 地盤沈下時の埋設管路挙動を示 す有効な解であるといえる.

\section{（2）等価地盤ばね定数}

地盤ばねの非線形性を, Fig. 19 に示すようなバイリ

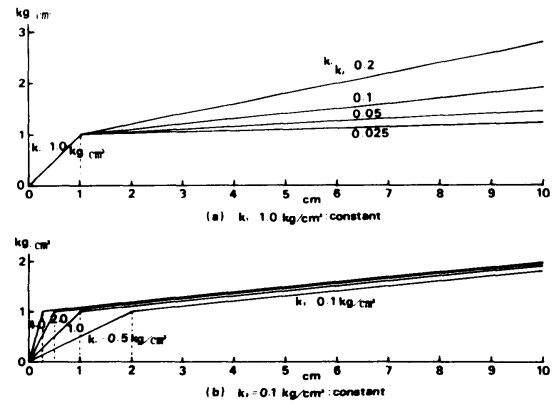

Fig. 19 Model of Nonlinear Spring.

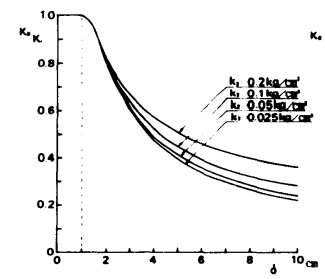

(a) k. $1.0 \mathrm{~kg} / \mathrm{cos}$. constem

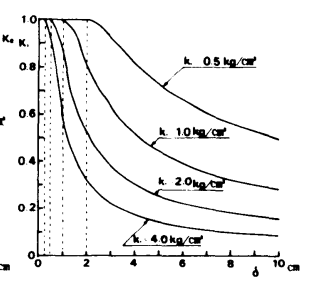

(b) $\mathrm{k}, 0.1 \mathrm{~kg} / \mathrm{cor}$ : constam
Fig. 20 Equivalent Spring Constant.

ニア型で表現し，バイリニア型の地盤ばねを有するはり の有限要素法による解と, 2. において示したタイプI の解析解とを比較する.

Fig. 19 に示す地盤ばねを有するはりの有限要素法に よる各视下量における最大曲げモーメント $M_{\mathrm{F}_{\max }}$ と, 同一沈下量における解析解による最大曲げモーメント $M_{\text {I max }}$ (式 (5)) とが等しくなるように, 解析解の地 盤ばね定数を決定し，これを，等価地盤ばね定数 $k_{e}$ と する。

等価地盤ばね定数 $k_{e}$ は,

$$
\begin{aligned}
& M_{F_{\text {max }}}=M_{I_{\text {max }}}=-2 E I \cdot \delta \cdot \beta^{2} \\
& K_{y}=k_{e} \cdot D \\
& k_{e}=\frac{M_{\mathrm{F} \max }^{2}}{E I \cdot D \cdot \delta^{2}}
\end{aligned}
$$

となる.ここで， $D:$ 管径, $\delta$ : 任意の地盤沈下量, で ある.

Fig. 20（a）に，地盤ばねの第 1 勾配 $k_{1}$ が，1.0 $\mathrm{kg} / \mathrm{cm}^{3}\left(9.8 \mathrm{MN} / \mathrm{m}^{3}\right)$ ，第 2 勾配 $k_{2}$ が， $0.025 \sim 0.2$ $\mathrm{kg} / \mathrm{cm}^{2}\left(0.245 \sim 1.96 \mathrm{MN} / \mathrm{m}^{3}\right)$ と可変する場合の等価 地盤ばね定数を示す. 第 1 勾配に対する等価地盤ばね定 数の比 $k_{e} / k_{1}$ は, 地盤沈下量 $5 \mathrm{~cm}$ のとき, $0.39 \sim 0.51$, 地盤沈下量 $10 \mathrm{~cm}$ のとき, $0.22 \sim 0.36$ となり, 地盤沈 下量の増大とともに，第 2 勾配の影響が大きく現われて いる. Fig. 20 (b)，に，地盤ばねの第 1 勾配 $k_{1}$ が, $0.5 \sim 4.0 \mathrm{~kg} / \mathrm{cm}^{3}\left(4.90 \sim 39.2 \mathrm{MN} / \mathrm{m}^{3}\right)$ と可変で, 第 2 勾配 $k_{2}$ が, $0.1 \mathrm{~kg} / \mathrm{cm}^{3}\left(0.98 \mathrm{MN} / \mathrm{m}^{3}\right)$ の場合の等価 地盤ばね定数を示す. 第 1 勾配が大きいほど, 地盤沈下 量の增大による $k_{e} / k_{1}$ の減少割合は, 大きい. また, $k_{e} /$ $k_{1}$ の減少割合は, 地盤沈下量の増大に伴い, 順次小さ くなり，一定値へ漸近していくが，その傾向は，第 1 勾 配が大きいほど，早く現われる. Fig. 20 は，管路 $600 \mathrm{~A}$

(外径 $609.2 \mathrm{~mm}$, 肉厚 $9.5 \mathrm{~mm}$ ) を対象に作成した等 価地盤ばね定数であるが, 対象管路を, $150 \mathrm{~A}$ (外径 $165.2 \mathrm{~mm}$, 肉厚 $5.0 \mathrm{~mm}$ ) に変化させた場合も, その值は, ほとんど変化しない。

Fig. 21 に，600 A に対するバイリニア型の地盤ばねを 有するはりの有限要素法による曲げモーメント図と, 等 価地盤ばね定数を用いた解析解の曲げモーメント困を示 


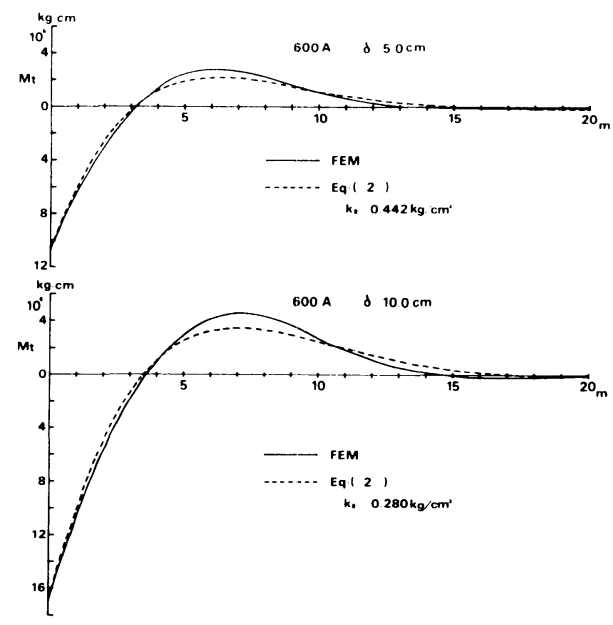

Fig. 21 Comparison between FEM Solution and Analytical Solution.

す.なお，バイリニア型の地盤ばねとして $k_{1}=1.0$ $\mathrm{kg} / \mathrm{cm}^{3}\left(7.8 \mathrm{MN} / \mathrm{m}^{3}\right), \quad k_{2}=0.1 \mathrm{~kg} / \mathrm{cm}^{3}\left(0.98 \mathrm{MN} / \mathrm{m}^{3}\right)$ を用いているので，地盤等価ばね定数としては，Fig. 20 (a) より, 地盤沈下量 $5 \mathrm{~cm}$ のとき, $k_{e}=0.442 \mathrm{~kg} / \mathrm{cm}^{3}$ $\left(4.33 \mathrm{MN} / \mathrm{m}^{3}\right)$, 地盤沈下量 $10 \mathrm{~cm}$ のとき, $k_{\boldsymbol{e}}=0.280$ $\mathrm{kg} / \mathrm{cm}^{3}\left(2.75 \mathrm{MN} / \mathrm{m}^{3}\right)$ を用いている. Fig. 21 において 明確なように，固定端より $7 \mathrm{~m}$ 付近において，若干の 差異はあるが, モーメント分布図は, 概略的によく一致 している.なお，150 Aに対するモーメント分布図も，

Fig. 21 と同様の傾向を示す.

つまり，管径 $600 \mathrm{~mm}$ 程度以下の埋設管路の地盤沈下 解析においては，非線形ばねを有する有限要素法解析を 実施しなくとも，Fig. 20 に示す等価地盤ばね定数を用 いた線形解析解の適用によって，十分その挙動を表現す ることができると思われる.

\section{5. 結 論}

地盤沈下による埋設管路挙動と，その基本的対策案に 関して, 解析的・実験的に種々の考察を加え, 以下に示
すような結論を得た。

（1）埋設管路に影響を与える地盤沈下形態を 3 つに 分類し, それらの解析解を誘導した. 解析解によると夕 イプI（固定構造物に接続している埋設管路に対する地 盤沈下) が, 他の 2 つタイプに比べ, 単位沈下量に対 する発生断面力が最も大きく，地盤沈下に対する埋設管 路挙動を考える場合, 最も考虑すべき地盤沈下形態とい える.

（2）沈下防止板は，タイプIの地盤沈下対策として 有効であることが, 解析的のみならず実験的にも確かめ られたが，沈下防止板を設ける場合，その長さは， $3 \pi /$ $4 \beta^{\prime}$ 以上必要である.

（3）タイプIの解析解およびその基本的対策案に関 する解析解は, 実験結果ともよく一致し, 地盤沈下時の 埋設管路挙動を示す有効な解である.

（4）中・小口径の埋設管路の地盤沈下解析において は, 非線形ばねを有する有限要素法解析を実施しなくと も, 等価地盤ばね定数を用いた線形解析解の適用で, 十 分その挙動を表現できる.

\section{参 考 文 献}

1）堀内孝英：地中埋設管の最適設計法に関する研究 学位 論文, pp. $63 \sim 129$, 昭和 55 年 5 月.

2）片山恒夫 - 增井由春 - 磯山龍二- 甚内郁朗：1978 年宮城 県沖地震による都市供給施設の被害と復旧一都市ガス施 設 , 生産研究, 31 巻 2 号, 1979 年 2 月.

3）青鹿勝之・高野護国 : 不等沈下地盤中のパイプライン解 析，日本鋼管技報，No. 57, pp. 61 73，1972 年 9 月.

4）高田至郎・山部泰男：沈下土槽による埋設管路の大変形 挙動実験とその解析, 土木学会論文報告集, 第 323 号, pp. 55 66, 1982 年 7 月.

5）関口宏二・大石 博：地盤の部分的変形による埋設管路 断面力の簡易計算法, 第 38 回土木学会年次学術講演会, pp. $221 \sim 222,1983$ 年 9 月.

6）菊地征也・安延信一・伊藤陽三：地中管路の強制沈下実 験について, 第 36 回土木学会年次学術講演会, pp. 466 $\sim 467,1981$ 年 10 月

(1984.6.6 • 受付) 